Јелена Недић

Универзитет у Београду

Православни богословски факултет

nedichelena@yandex.ru
УДК 811.161.1'367.625: 811.163.41'367.625 https://doi.org/10.18485/slavistika.2018.22.2.11 оригинални научни рад примљено 01.03.2018. прихваћено за штампу 04.10.2018.

\title{
ГЛАГОЛСКИ ОБЛИЦИ У ИТЕРАТИВНИМ КОНСТРУКЦИЈАМА У РУСКОМ И СРПСКОМ ЈЕЗИКУ
}

У раду се покушава обухватити и представити богатство и разноврсност глаголских средстава и њихових итеративних значења, као и могуће комбинације њихових еквивалената у српском и руском језику. Уочава се неограничено-вишекратно, егземпларно, квалификативно, пословично значење, као и значење дезактуализованости, уобичајене радње и епизодичног понављања код итеративних конструкција у руском и српском језику. Кроз контрастивну анализу утврђују се језичка средства којима се ова значења изражавају.

Кључне речи: итеративност, глаголска квантификација, хабитуалност.

In this paper an attempt is made to present the richness and diversity of verb aspects and their iterative meanings, as well as variants of their equivalents in Russian and Serbian. Unrestrictedmultiple, evident-exemplary, qualifying, proverbial values are allocated, as well as the values of deactualization, ordinary action and episodic repetition. With the help of contrastive analysis, possible options for the expression of these values are established. The forms of the perfect and imperfect aspect are analyzed, the modes of the verbal action, and some special forms for expressing iterative values (constructions with the verbs бывало, доводится, приходится, любить) in the Russian language, as well as aspectual forms, potentials and special constructions for expressing iteration (with modal verbs, with the verbs дешавати се, догађати се, волети, etc.) in the Serbian language.

Key words: iteration, verbal quantification, habituality.

Итеративност је аспектуална категорија која одређује ситуацију у погледу њене поновљености у времену. Квантитативни глаголски аспекат је најмање граматикализован у аспектологији, зато још увек постоји велики број нерешених питања у вези са њим. Вишекратна радња се маркира у реченици помоћу граматичких, творбених, лексичких, синтаксичких и контекстуалних средстава, која се најчешће користе сва скупа.

Термин итеративност је вишезначан. Код истраживача може да означава све типове мноштвених конструкција или само један тип.

Што се тиче типологије итеративних конструкција, постоји неколико класификација. Најпотпунија и најаргументованија класификација припада В. С. Храковском (Храковский 1989). Он разликује мултипликативни (један временски период, идентичан скуп актаната), дистрибутивни (један временски период, неидентичан скуп актаната) и итеративни (различити временски периоди, идентичан скуп актаната) тип вишекратних ситуација (в. такође: Храковский 2014; Fedotov 2015).

Нас овде интересује итеративност у ужем смислу, што значи да радом нису обухваћене мултипликативне и дистрибутивне радње ${ }^{1}$.

${ }^{1}$ Детаљнији осврт на постојеће класификације итеративности може се наћи у раду: Недић 2016. 
Итеративност у ужем смислу, полазећи од Храковског, дефинишемо као такво мноштво процесуалних ситуација које се одликује унутрашњом рашчлањеношћу ситуације, политемпоралношћу (тј. све ситуације које улазе у итеративно мноштво одвијају се у различитим временским периодима), и подударношћу учесника (тј. сваку ситуацију одликује идентичан скуп актаната) (Храковский 1989: 41; 2015: 147-150).

У овом раду у оквиру итеративности издвајамо више значења, а због специфичности нашег истраживања крећемо се двосмерно: од значења ка форми и обратно, од облика ка значењу. Свакако, с обзиром на обим рада и ширину теме, не можемо да претендујемо на исцрпност, али смо покушали да обухватимо и представимо богатство и разноврсност глаголских средстава и итеративних значења и могуће комбинације њихових еквивалената у српском и руском језику.

Итеративни тип вишекратности ситуација неки истраживачи деле на подтипове, полазећи од значења вишекратне ситуације ${ }^{2}$. Код једних подтипова доминантна је опозиција једнократност / вишекратност (конкретно вишекратно, узуално значење), код других (резултативно, потенцијално значење) у фокусу није опозиција једне радње и мноштва радњи, него својство, квалитет, стање субјекта, док се код трећих (са генерализованим субјектима) потпуно губи својство квантификативности. Зато неки истраживачи у итеративност у ужем смислу сврставају само конкретно вишекратно и узуално значење (уп. нпр.: Војводић 2003; Барентсен 2008; Lehmann 2013; Бенаккьо, Пила 2015; Дерганц 2015)

Међутим, у одређеном броју радова веома важну улогу има сплет итеративних значења код неких језичких средстава који може сведочити о међусобној повезаности и заједничким коренима из истог процеса семантичке промене и граматикализације (Hellman 2005, Ивановић 2016).

Наша анализа језичког материјала такође је довела до потребе за обрађивањем неколико разних значења у склопу једног итеративног (хабитуално значење разматрамо у оквиру итеративности) $)^{3}$.

Када је реч о словенским језицима, у литератури посвећеној глаголском виду увек ћемо срести вишекратност радње као једно од значења несвршеног вида. Исто тако, у литератури посвећеној итеративности не можемо да заобиђемо глаголске облике несвршеног вида јер је то најфреквентнији облик којим се изражава вишекратност радње. Нећемо детаљно анализирати семантику и облике несвршеног вида, ком је посвећен велики број посебних студија ${ }^{4}$. Упоредићемо укратко његову употребу у руском и српском језику.

И у руском и у српском језику облици несвршеног вида се слободно употребљавају на плану садашњег, али и прошлог времена, са неограничено-више-

${ }^{2}$ У Теорији функционалне граматике (ТФГ. Качественность. Количественность) Долињина, сумирајући податке изложене у радовима који се баве питањима значења видсковременских глаголских облика, даје списак итеративних значења: Долинина 1996: 233-234.

${ }^{3}$ Спомињали смо то у излагању о глаголским облицима у итеративним конструкцијама у руском и македонском језику на Међународном скупу слависта на Филолошком факултету Универзитета „Св. Ћирило и Методије“ у Скопљу (2017); уп. сличан приступ у: Војводић 2003; Шольце 2015.

${ }^{4}$ За руски језик то су, пре свега, радови из аспектуалности: Маслов 1948; 1978; 1984; Бондарко 1971 и др.

Славистика XXII/2 (2018) 
кратним значењем ${ }^{5}$, тј. облик несвршеног вида означава неограничени низ поновљених радњи: И вот к экзаменам Симочка и её подруги пи сали большое количество шпаргалок, прятали в недоступные для мужчин места женской одежды, а на экзамене вытаскивали нужную и, разгладив, выдавали её за листок подготовки. (А. И. Солженицын, В круге первом). Серенькие «волчки», пичуги, будут деловито порхать, прятаться в кипарисах, утрами будут стрекотать сойки ... (И. Шмелев, Солнце мертвых) Sa sinom je iz la zi la i išl la po rodbini... (B. Stanković, Nečista krv). Глаголи несвршеног вида се могу користити за изражавање вишекратне ситуације на плану садашњости, прошлости и будућности. У изражавању итеративности активно учествују и глаголске одредбе, захваљујући којима глаголе несвршеног вида можемо тумачити као вишекратне. Ради се, пре свега, о прилозима 6 .

И у српском и у руском језику постоје одређене акционалне класе глагола са итеративним значењем (уп. нпр.: Бенаккьо, Пила 2015: 83-88). У руском језику су то вишекратни беспрефиксални глаголи који се граде додавањем суфикса -ыва- / -ива и -а- / -ва- (бывал, едал, видывал, даривал).

Ови глаголи су експресивно маркирани и у савременом књижевном језику су мање заступљени него некада. Међутим, префиксални итеративни глаголи са додатним значењем смањеног итензитета (,прерывисто-смягчительный способ действия") са суфиксом -ыва- / -ива попут захаживать, посматривать, прикрикивать се веома активно користе: Он сидел, покачивая головой и плечами, как еврей во время молитвы, - глаза в одну точку, пальцы крепко сиеплены. (Л. Улицкая, Лестнииа Якова $)^{7}$; Она открыто смотрела на Глеба, и тонкие бровки её подрагивали. (А. И. Солженицын, В круге первом); Она давно взглядыв вала на Нержина со строгим неодобрением. (А. И. Солженицын, $B$ круге первом). У српском језику постоји слична класа (глаголи попут подвикивати) са истим суфиксом. Глаголе образоване додавањем суфикса $-a-$ / -ва- попут доставать, давать такође можемо сматрати итеративнима јер у већини контекста имају вишекратно значење. У српском језику постоји група глагола несвршеног вида са суфиксима -ja-, -ива-, -ава-, који увек имају итеративно значење (похађати, виђати, ручавати, ноћивати $)^{8}$. Међу итеративним глаголским класама у руском језику треба навести и комитативновишекратну, коју можемо издвојити и у српском језику. У руском језику она је маркирана претежно циркумфиксом пере-...-ся (перекрикиваться, переговариваться), а у српском до- се (довикивати се, дописивати се, добацивати се). Такође ћемо споменути и репетитивну класу глагола са префиксом пере- (пере-

${ }^{5} \mathrm{O}$ неограничено-вишекратном значењу несвршеног вида у руском језику в., поред осталог: Knjazev 2013; уп.: Храковский 2014; 2015; Бенаккьо, Пила 2015; Дерганц 2015. О ограничено-вишекратном значењу несвршеног и свршеног вида (које се у овом раду не разматра) у руском, српском и другим словенским језицима в., нпр.: Барентсен и др. 2015.

${ }^{6}$ О њиховој улози у изражавању итративности у руском и српском језику в. Недић 2017.

${ }^{7}$ Говорили смо о томе у оквиру излагања о глаголским облицима у итеративним конструкцијама у руском и македонском језику на Међународном скупу слависта на Филолошком факултету Универзитета „Св. Ћирило и Методије“ у Скопљу (2017). Међутим, требало би додатно истражити употребу различитих префиксалних и непрефиксалних глагола са суфиксима -blвa- / -ива, те са сигурношћу установити да ли постоји законитост везана за префиксе.

${ }^{8}$ Детаљније о таквим глаголима у српском језику в. у: Ивановић 2013. 
писывать, перечитывать), која у комбинацији са одредбама за вишекратност у руском језику може да учествује у изражавању итеративности: Иногда перечитываю те два письма, которые он написал мне в Сталинградскую (Л. Улицкая, Лестница Якова). У српском језику можемо издвојити несвршене глаголе са префиксом из- (ишчитавати), који имају вишекратно значење са додатном семантиком. За њих у руском језику не постоји потпуни еквивалент, него би се употребио репетитивни глагол са одредбом за вишекратност, али би додатна семантика била изгубљена: перечитыввать много раз.

Свршени вид, такође, у оба језика може изражавати итеративно значење, али у руском језику његова употреба је ограниченија него у српском језику. Сада ћемо упоредити употребу презента свршеног вида у два језика којима се у овом раду бавимо.

У руском језику презент свршеног вида обично се користи у вишекратно-корелативном конструкцијама (које, према Ј. С. Маслову (Маслов 1959: 244-245), могу бити кратно-парные и кратно-цепные). Вишекратно-парне конструкције синтаксички представљају зависно-сложене реченице у чијем једном делу је употребљен облик свршеног вида, а у другом најчешће облик несвршеног вида. У руском језику у таквим реченицама се обично користе везници если, когда, как только, после того, как, пока:

Если понравился - все о тдаст. Чувствуют шутку. Ярко ненавидят. (Л. Улицкая, Лестница Якова).

У српском језику у таквим конструкцијама са истим значењем такође може бити употребљен облик свршеног вида са везницима када, чим, пошто, кад год, након штто, док и др. (в. нпр.: Kravar 1977/1978; уп. Барентсен 2008):

Кад уђ у у собу, закључају се. (Ј. Игњатовић, Вечити младожења). Мој pas $i$ moj tata vode rat za mesto u kući. Čim tata sedne u fotelju pas trči i laje da se pomeri da bi on tu lego. Kad tata noću us tane iz kreveta pas obavezno le gne na njegovo mesto, i neće da se pomeri nikako da bi tata legao da spava (разг.) Међутим, поред презента свршеног вида користи се и облик потенцијала. Облик потенцијала, који може да буде и свршеног и несвршеног вида, може бити употребљен у оба дела реченице:

Kad bi moj muž završio sa poslom ja bih spremila večeru, bila tu za svaku želju, na kraju gledal film $i$ on bi zas pao u zagrljaju i meni je to bilo najlepše (разг.)

Облици потенцијала учествују у реализацији таксиса при понављању ситуације (ради се о комплексном односу видских и темпоралних показатеља који упућују на одређени тип таксисних односа - антериорност, симултаност, непотпуну симултаност, постериорност). Ово питање детаљно разматра Љ. Поповић (Поповић 2012: 117-128).

И облик презента свршеног вида и облик потенцијала у српском језику користе се такође у конструкцијама са везницима кад год, где год, шта год ${ }^{9}$ : Где год би се нашао неки камен у пољу или шуми, веровало се да је ту нека-

${ }^{9}$ У овим, као и у зависносложеним реченицама са другим везницима, зависна реченица указује на околности у којима се ситуација понавља.

Славистика XXII/2 (2018) 
да манастир био који су Турии порушили, кад Лазара посекоше на Косову. (Д. Ћосић, Корени)

У другом типу ових конструкција, вишекратно-ланчаном, нема зависних односа, него је заступљен неограничени низ поновљених радњи који могу да се понављају са истом или различитом учестолашћу. У вишекратно-ланчаним конструкцијама корелација радњи се заснива на узастопном додавању следећег елемента конструкције претходном елементу. Ситуација која се састоји од наизменичних узастопних радњи изражава се низом предиката: Павлин тоже прознал дорогу. Но - вымахнет хвостом из пшеницы и попадется грекам. Они поднимают крик, гонят воров и приходят к моим воротам (И. Шмелев, Солнце мертвых);

Служебные обязанности мои следуюшие: в девятом часу разбираю бумаги c почты, пииу донесения, рапорты, приказания, отношения. В десять часов приходит батальонный, подписывает все, и в двенадиатом часу уходит. И я совершенно свободен. Вечером схожу к нему на квартиру с докладом, и все кончено до утра (Л. Улицкая, Лестница Якова). Овај пример је интересантан због тога што је облик свршеног вида употребљен слободно, ван конструкције, а ситуацију понављања низа радњи видимо у ширем контексту, тј. ван оквира реченице. Самим тим отвара се и питање ширег контекста. О типу контекста за сада не можемо ништа рећи јер је неопходно посебно проучавање ширег контекста који обезбеђује вишекратно тумачење радњи.

Што се тиче српског језика, у ситуацијама где је изражен низ радњи које се понављају поред облика презента свршеног вида може се такође употребљавати и облик потенцијала (уп., поред осталог: Kalsbeek, Lučić 2008): Sećam se, kad smo bile mlade, mama bi vikendom u vek sla la tatu da budi mene i sestru. Njemu bi bilo žao, pa bi nas pustio da se naspavamo, a onda kad ga mama pretisne, on uđe u sobu, pus ti muziku io dvali na najjače i budi nas rečima: Dobro jutro radni narode Crne Gore, tačno je 12 sati... $i$ onda bi s e s m ej a o, p eva glasno $i$ ne bi stišao muziku sve dok ne ustanemo (разг.)

У таквим типовима конструкција постоје следећи типови видског контекста: низ наизменичних чињеница (И то нахмур ится, то засв и стит, то захохочет, как безумный. Паустовский, Наш современник), низ чињеница које се међусобно искључују (Если он проходил мимо работающих..., он тотчас же брался помогать - или пройдет ряда два с косой, или нав вет воз, или срубит дерево, или поруби дров. (Л. Н. Толстой, Хаджи-Мурат)), скуп чињеница (Иной бывальй сибиряк скажет, что тайга, мол, всегда и при ве mи и, инакормит, и согреет. В. Чивилихин, Серебряные рельсы). У таквим реченицама у српском језику такође се може користити облик свршеног вида (Шьљахтеи кошта ракију, допада му се, пије, узме који залогај, па опет nuје. Јаков Игњатовић, Вечити младожења), али и облик императива са везницима час и сад: Цео дан ми прође у послу: час тр чи овамо, час онамо, сад устани, сад седни (разг.). Сваки дан ко рачај по увалама, пентрај се са секиром по врлетима: п р и премај огрев за зиму (И. Шмељов, Сунце мртвих).

Једно од конкретних значења свршеног вида је значење које А. В. Бондарко назива „наглядно-примерное“ (Бондарко 2005: 383-384). Такав облик из- 
ражава уобичајену радњу која се понавља, код које се издваја један од аката понављања као очигледан пример уобичајене радње:

Я сташил у нее месяи тому назад связку ключей и, таким образом, получил возможность выходить на общий балкон, а он тянется вокруг всего этажа, и, таким образом, иногда нав ести и ь соседа (М. Булгаков, Мастер и Маргарита).

За изражавање овог значења најчешће се користе облици прошлог времена свршеног вида и инфинитива, ређе облици будућег времена свршеног вида, потенцијала и кратки облици трпних глаголских придева ${ }^{10}$.

Треба да напоменемо да у српском језику, за разлику од западних и источних словенских језика, презент свршеног вида нема значење будућег времена, због чега се много шире употребљава како на плану садашњег, тако и на плану прошлог и будућег времена ${ }^{11}$. У одређеним ситуацијама глагол свршеног вида садашњег времена може да означава итеративну радњу, и његова употреба у овом контексту је доста шира него у руском језику, тј. овај облик се редовно користи и ван вишекратно-корелативних конструкција (када облик свршеног вида има конкретно итеративно значење), с тим што радња која је изражена тим глаголом може да се - у зависности од контекста - транспонује како на план прошлости, тако и на план садашњости:

Између нас, док бдимо, и намег друга који спава ст во ри се увек хладан и велик размак који расте са сваким минутом и пуни се све више... (И. Андрић, Жеђ)

Чамчиница их теши и, премда и она би већ волела свог Чамчу код куће имати, није веровала да их је могло што зло постићи, јер то је обично код Чамче да увек дуже о стане него што је код куће обрекао... (Ј. Игњатовић, Вечити младожења)

За руски језик таква, слободна, употреба свршеног вида није уобичајена, али се може срести у народном језику, зато у бајкама постоје такви примери:

Наденет кольио... Ровно как раз впору, не жмет, не скатывается, а пойдет в церкву или в гости куда - замается. Как закованный палеи-то, в конце нали посинеет. Серьги навесит -хуже того. Уии так о т т я н ет, что мочки р а спухн ут. А на руку взя ть - не тяжелее тех, какие Настасья всегда носила (П. Бажов, Малахитовая шкатулка).

Такође треба рећи да се свршени вид презента у српском језику може користити и у изражавању вишекратне ситуације чије значење тежи пословичном. Када је у питању такво, атемпорално, односно омнитемпорално значење, субјекат радње је уопштен, а радња која се понавља обично се односи на групу људи или на све људе уопште:

Ко прориче најгоре ствари, увек п ого д и! (М. Капор, Ивана)

Поред тога, у српском језику свршени вид презента може имати и квалификативно значење (у руском се овде користи облик несвршеног вида):

\footnotetext{
${ }^{10}$ Детаљније о тим облицима в. у Бондарко 2005: 239; уп. Бенаккьо, Пила 2015: 81-88.

${ }^{11}$ Слична широка употреба свршенога вида у итеративном значењу карактеристична је и за словеначки језик иако презент свршеног вида може да има (као и у западним и источним словенским језицима) значење будућег времена премда пре свега у специфичним случајевима/контекстима (уп. Дерганц 2015).
}

Славистика XXII/2 (2018) 
Малина не иде у пијано воће, она се расп адн н (разг.)

Квалификативно значење у српском језику може се изразити и обликом футура првог:

Он ће увек доћи, кад год затреба (разг.). Још М. Стевановић назива такав облик квалификативно будуће (Стевановић 1989: 673).

Облик футура првог, може се, међутим, користити и за изражавање уобичајене радње која се понавља, али ипак треба напоменути да се у савременом језику овај облик не користи редовно за изражавање овог значења, што смо закључили на основу нашег корпуса:

Калфе није имао, држао је само једног шегрта, а кад је много муштерије или гостију било, морали су сви помагати, и сама служсавка, а и сам је служио. На по године пре него што ће шегрта ослободити, узеће новог, да се мало увежба, а имао је већ и једног сина, који је помагао. (Ј. Игњатовић, Вечити младожења).

За изражавање уобичајене радње у српском језику се користи и облик императива (већ смо га споменули горе), али ни он није редован у савременом језику у оваквом контексту ${ }^{12}$ :

Купих једне године краву с Чева, бијесну музовнииу, која ми данимище даваме по по виједра млијека, свако јој виме као мијех од шиљежеве коже. Поженем је дома и даднем своме кметићу да ју чува: почне да јој танча млијеко, ли и ај данас, лињ ај сутра, док јој се груди пресуше... (Ст. М. Љубиша, Сједи криво, ал'суди право)

Поред горе размотрених глаголских облика, и у руском и у српском језику постоје различите конструкције са глаголима које имају итеративно значење. Неке од њих су истраживане, зато их нећемо детаљно анализирати у овом раду.

Навешћемо пре свега конструкцију састављену од глагола бывало и глагола свршеног или несвршеног вида у руском језику. На ове конструкције у контексту итеративности се осврће М. Ивић (1983). Исте конструкције, али у украјинском језику (буває, бувало и було), као и њихове српске еквиваленте, разматра и М. Ивановић, чији закључци су примењиви и на руски језик (Ивановић 2016).

Конструкције са глаголом бывало могу имати епизодично значење (нередовно понављање радње) (Ивић 1983: 38):

Придворньй календарь не попадался ему на глаза иногда по иельм месяиам. Зато, когда он случайно его находил, то, бы вало, по иелым часам не в ы скал уж из своих рук. (А. С. Пушкин, Капитанская дочка).

Овом значењу у српском језику одговарају конструкције са значењем дешавати се, догађати се (+ да-констр.), као и конструкције са глаголом бивати (бива $+\partial a$-констр.):

Много је волео да буде са породицом, али се ипак деш ав ало да се врат и јако касно (разг.)

Конструкције са глаголом бывало могу имати и значење дезактуелизованости. Овом значењу у српском језику одговара облик потенцијала, што потврђују и примери из превода:

\footnotetext{
${ }^{12}$ Овај закључак је такође изведен на основу нашег корпуса.
} 
Други пут, кад би нам го вор ио о владаюу, рекао би нам... (Б. Нушић, Аутобиографија) / В другой раз, разбирая вопрос о нашем поведении, он, б ьлв ал о, говорил нам... (Б. Нушич, Автобиография)

Код конструкција са глаголом бывало и основним глаголом свршеног вида М. Ивић издваја егземпларно значење (Ивић 1983: 46). Ово значење, али под другим називом („наглядно-примерное“, према А. В. Бондарку), већ смо описали горе. Пример: Как з а в ижу, б ы вал о, рысьи шапки, да как з а сл ы шу их визг, веришь ли, отец мой, сердие так и з а м ре дочка). Сматрамо да је веома тешко одредити да ли таквом значењу (односно тумачењу) доприноси глагол бывало или свршени вид глагола који и ван ове конструкције може да га поседује. У сваком случају, у српском језику овим конструкцијама одговарају исти облици као и егземпларном свршеном презенту, тј. презент или потенцијал свршеног вида: Живан се склонио у сенку; и кад се јав и, юегов глас је сада мање јасан. (И. Андрић, Жеђ).

Такође, конструкције са глаголом бывало могу имати и квалитативно, генеричко значење. У овом случају њима су у српском језику еквивалентне конструкције са модалним глаголима умети, знати, моћи и хтети, као и конструкције имати навику да + презент: он зна да попије, он хоће да помогне. Конструкције са глаголима знати и умети је истраживао Хелман (Hellman 2005), док конструкцијама са глаголима моћи и хтети није посвећивано много пажње, осим што их кратко разматра М. Ивановић (2016), а конструкције имати навику да + презент нису истраживане (в. такође: Kravar 1963/1964; Радовановић, Војводић 2005).

У руском језику са овим значењем, поред конструкција са глаголом бывало, могу се срести и конструкције са глаголом любить, које нико од истраживача не наводи у контексту итеративности, иако оне такође могу имати квалификативно значење. Да би нам њихова итеративна семантика била очигледнија, можемо их трансформисати на следећи начин: Он любит выпить $=$ Он часто выпивает.

У српском језику се такође користе конструкције са глаголом волети (уп. Танасић 1999: 42-43). Следећи пример добро илуструје итеративно значење таквих конструкција: На свадбама Младен воли да запева (разг.). Овде се не реализује семантичко значење глагола, него итеративно значење целе конструкције јер то не значи да се Младену само свиђа да пева на свадбама, него да он и заиста редовно пева на свадбама.

Навешћемо још један пример из руског језика:

К тому же не был он (по его выражению) и врагом бутылки, т. е. (говоря по-русски) любил хл ебнуть лишнее. (А. С. Пушкин, Капитанская дочка).

Постојећи превод потврђује исту употребу у српском језику:

Sem toga, nije bio (kako je sam kazivao) ni neprijatelj čaši, tj. (govoreći ruski) vo leo je da gucne. (A. S. Puškin, Kapetanova kći).

Ово значење се реализује у конструкцијама са глаголом свршеног вида, често у комбинацији са лексичким средствима која упућују на поновљеност / цикличност, или пак у вишекратно-парним конструкцијама.

Славистика XXII/2 (2018) 
Требало би навести и конструкције са облицима доводится / доводилось, $n p u$ ходится / приходилось у руском језику чија итеративна семантика је очигледна и које су истраживачи занемарили у овом погледу (Я начал вспоминать разные бейсбольные матчи, которые мне случалось в идеть; Вероятно, вам доводилось слышать о моем отие). Чини нам се да оне имају иста значења као и конструкције са глаголом бывало, али би то требало додатно истражити.

Исто тако, чини нам се да би овде требало навести и конструкције са почетним глаголима у функцији помоћних (који постоје и у руском и у српском језику), нпр.: С тех пор дядя с тал приходить к нам каждый день; Otkako sam p o č ela da hodam na posao (5 $\mathrm{km}$ tamo i nazad), osećam se mnogo bolje nego $i k a d$. (разг.). Уп. такође прву строфу „понародњене“ песме песника и композитора Драгише Недовића, где се глагол стати (у аористној форми) користи (као и глагол стать у руском језику) са значењем почетка (итеративне) радње: Стаде се ивеће росом китити / Стаде се бисер златом низати / Стаде се срма срмом срмити /Стадоме момичи иуре просити. Свакако, улогу у изражавању итеративности могу играти и одредбе, јер се итеративност најчешће изражава у комбинацији лексичких, граматичких и контекстуалних средстава. Међутим, у неким примерима итеративно значење несвршеног вида, по нашем мишљењу, актуализује се управо захваљујући почетном глаголу: Tym начал он з е в а mb и приказал отвести себя в свой нумер, где, прилегши, заснул два часа (Гоголь, Мертвые души).

Осим ових фазних (почетних) глагола могу се разматрати и конструкције са другим фазним глаголима попут продолжать, који такође поред трајности могу да - у зависности од семантике главног глагола - означавају и вишекратност:

Писатели умирают, а их творения пр одол ж аю $m$ с последующими эпохами жить, стариться, умирать и снова воскресать (Л. Улицкая, Лестнища Якова).

- Добро, добро, идемо даље - заустави га учитељииа и настави да испитује друге прваке. (Б. Ћопић, Глава у кланиу, ноге на враниу).

Ове конструкције истраживачи нису анализирали у контексту итеративности.

С обзиром на све речено, можемо да резимирамо следеће:

- што се глагола тиче, у српском језику постоји више могућности за изражавање итеративних значења (у руском језику то су пре свега глаголи несвршеног и свршеног вида, у српском језику - глаголи несвршеног и свршеног вида, облици императива, футура првог, облик потенцијала);

- неки од облика који се користе у оба језика могу се шире употребљавати у једном од језика;

- за један облик у једном језику не постоји један еквивалент у другом језику, једном облику може да одговара више облика у другом језику, а све у зависности од итеративног значења и контекста и обрнуто (облицима потенцијала и глаголима свршеног вида у српском језику може да одговара глагол свршеног вида у руском језику, глаголу несвршеног вида у руском језику могу истовремено одговарати облици футура првог, императива, глагол свршеног вида и сл.);

- неки облици и конструкције нису довољно истражени у два језика која нас интересују, па би им требало посветити пажњу у даљим истраживањима. 


\section{Цитирана литература}

Барентсен, Адриан. «Выражение последовательности действий при повторяемости в прошлом в современных славянских языках». [In:] P. Houtzagers, J. Kalsbeek, J. Schaeken (eds.). Dutch Contributions to the Fourteenth International Congress of Slavists: Linguistics / Ohrid, September 10-16. Amsterdam - New York: Rodopi, 2008, 1-36 (Studies in Slavic and general Linguistics 34).

Барентсен, Адриан, Рене Генис, Магда ван Дейкерен-Грабова, Яннеке Калсбеек, Радован Лучић. «В поисках сходств и различий между русским, польским, чешским и сербохорватским языками при выборе вида в случаях ограниченной кратности». [В:] Р. Бенаккьо (ред.). Глагольный вид: грамматическое значение и контекст / Verbal Aspect: Grammatical Meaning and Context / III Междунар. конф. Комиссии по аспектологии Международного Комитета славистов (Падуя, 30.IX-4.X.2011 г.). München - Berlin - Washington/D.C.: Verlag Otto Sagner, 2015, 55-78 (Die Welt der Slawen: Sammelbände / Сборники 56; hrsg. von P. Rehder und I. Smirnov).

Бенаккьо, Розанна, Малинка Пила. «Глагольный вид в контекстах неограниченной кратности в словенском языке в сопоставлении с русским». [В:] Р. Бенаккьо (ред.). Глагольный вид: грамматическое значение и контекст / Verbal Aspect: Grammatical Meaning and Context / III Междунар. конф. Комиссии по аспектологии Международного Комитета славистов (Падуя, 30.IX-4.X.2011 г.). München - Berlin - Washington/D.C.: Verlag Otto Sagner, 2015, 79-91 (Die Welt der Slawen: Sammelbände / Сборники 56; hrsg. von P. Rehder und I. Smirnov).

Бондарко, Александр В. Вид и время русского глагола (значение и употребление). Ленинград: Просвещение, 1971.

Бондарко, Александр В. Теория морфологических категорий и аспектологические исследования / РАН, Ин-т лингвистических исследований. Москва: Языки славянских культур, 2005 (Studia philologica).

Војводић, Дојчил. „О синтаксичкој итеративности (на српско-руском материјалу)“. Славистика VII, 2003: 52-64.

Дерганц, Александра. «К употреблению глагольного вида в многократном/узуальном значении в словенском языке». [В:] Р. Бенаккьо (ред.). Глагольный вид: грамматическое значение и контекст / Verbal Aspect: Grammatical Meaning and Context / III Междунар. конф. Комиссии по аспектологии Международного Комитета славистов (Падуя, 30.IX-4.X.2011 г.). München - Berlin - Washington/D.C.: Verlag Otto Sagner, 2015, 171-178 (Die Welt der Slawen: Sammelbände / Сборники 56; hrsg. von P. Rehder und I. Smirnov).

Долинина, Инга Б. «Количественность в сфере предикатов (категория «глагольной множественности»)». [В:] А. В. Бондарко (ред.) Теория функциональной грамматики. Качественность. Количественность. Санкт-Петербург: Наука, 1996, 219-245.

Ивановић, Милена. „О категорији глаголске плуралности у светлу аспектуалности (на материјалу српског језика)“. Зборник Матице српске за филологију и лингвистику LVI/1, 2013: 77-87.

Ивановић, Милена. „Украјинске речце буває, бувало и було и њихови српски еквиваленти у функцији изражавања итеративности“. Славистика XX, 2016: 189-196. 
Князев, Юрий П. «Выражение повторяемости действия в русском и других славянских языках». [В:] В. С. Храковский (ред.) Типология итеративных конструкций. Ленинград: Наука, 1989, 132-145.

Маслов, Юрий С. «Вид и лексическое значение глагола в современном русском языке». Известия АН СССР, Отд. литературы и языка, т. 7, вып. 4, 1948: 303-316.

Маслов, Юрий С. «Глагольный вид в современном болгарском литературном языке (значение и употребеление)». [В:] С. Б. Бернштейн (ред.). Вопросы грамматики болгарского литературного языка. Москва: Изд-во АН СССР, 1959, 157-312.

Маслов, Юрий С. «К основаниям сопоставительной аспектологии». [В:] Маслов, Ю. С. (отв. ред.). Проблемы современного теоретического и синхронно-описательного языкознания, вып. 1: Вопросы сопоставительной аспектологии. Ленинград: Изд-во ЛГУ, 1978, 4-44.

Маслов, Юрий С. «Вид и лексическое значение глагола в современном русском литературном языке». [В:] Ю. С. Маслов, Очерки по аспектологии. Ленинград: Изд- во ЛГУ, 1984, 48-65.

Недич, Елена. «Итеративная множественность в русском, сербском и македонском языках». Зборник МС за славистику 81, 2012: 139-174.

Недић, Јелена. „Проучавање итеративности у руском језику“. Славистика XX, 2016: 182-188.

Недић, Јелена. „Прилози у изражавању квантификације предиката у руском и српском језику“. Славистика XXI/1-2, 2017: 131-139.

Поповић, Људмила. Контрастивна граматика српског и украјинског језика: таксис и евиденцијалност. Београд: САНУ, 2014.

Радовановић, Маја, Дојчил Војводић. „О једној језичкој универзалији (конструкције модалних глагола с инфинитивом у руском и другим словенским језицима)“. Славистика IX, 2005: 103-117.

Стевановић, Михаило. Савремени српско-хрватски језик (граматички системи и књижевно-језичка норма) II: Синтакса. Београд: Научна књига, 1989.

Танасић, Срето. „Семантика глагола и итеративност“. Јужнословенски филолог LV, 1999: 37-45.

Храковский, Виктор С. «Семантические типы множественных ситуаций и их естественная классификация». [В:] В. С. Храковский (ред.). Типология итеративных конструкций. Ленинград: Наука, 1989, 5-53.

Храковский, Виктор С. «Есть ли у несовершенного вида в русском языке повторительное (неограниченно-кратное / многократное / итеративное / узуальное / хабитуальное) значение?». Вопросы языкознания 4, 2014: 3-12.

Храковский, Виктор С. «Частные значения глаголов НСВ или контекстно-обусловленные аспектуальные значения высказывания с глаголом НСВ в русском языке». [В:] Р. Бенаккьо (ред.). Глагольный вид: грамматическое значение и контекст / Verbal Aspect: Grammatical Meaning and Context / III Междунар. конф. Комиссии по аспектологии Международного Комитета славистов (Падуя, 30.IX-4.X.2011 г.). München - Berlin - Washington/D.C.: Verlag Otto Sagner, 2015, 145-153 (Die Welt der Slawen: Sammelbände / Сборники 56; hrsg. von P. Rehder und I. Smirnov).

Шольце, Ленка. «Глагольный вид и повторяемость/хабитуальность в верхнелужицком и чешском языках (в сравнении с русским языком)». [В:] Р. 
Бенаккьо (ред.). Глагольный вид: грамматическое значение и контекст / Verbal Aspect: Grammatical Meaning and Context / III Междунар. конф. Комиссии по аспектологии Международного Комитета славистов (Падуя, 30.IX-4.X.2011 г.). München - Berlin - Washington/D.C.: Verlag Otto Sagner, 2015, 451-466 (Die Welt der Slawen: Sammelbände / Сборники 56; hrsg. von P. Rehder und I. Smirnov).

Fedotov, Maksim. „Iterativity, narrative, and aspect“. [В:] М. Китадзё (сост.). Аспектуальная семантическая зона: типология систем и сценарии диахронического развития / Сборник статей V Международной конференции Комиссии по аспектологии Международного комитета славистов (Киото, 13-15 ноября 2015 г.). Киото: Издательство «Tanaka Print» (Университет Киото Сангё), 2015, 314-320.

Hellman, Matias. The verbs znati and um(j)eti in Serbian, Croatian and Bosnian: a case study in the grammaticalisation of habitual auxiliaries. Helsinki: University of Helsinki, 2005.

Ivić, Milka. „Načini, na koje slovenski glagol ovremenjuje ponavljanu radnju“. [U:] Ivić, M. Lingvistički ogledi. Beograd: Prosveta, 1983, 37-56.

Kalsbeek, Janneke, Radovan Lučić. „Oblik kondicionala u funkciji označavanja ponavljane radnje u prošlosti“. Croatica et Slavica Iadertina IV, 2008: 7-21.

Knjazev, Juriy. «Источники неограниченно-кратной интерпретации несовершенного вида русском языке: лексическое значение, способ действия, синтаксис». [B:] M. Nilsson \& N. Zorikhina Nilsson (eds.). Семантический спектр славянского вида / The semantic scope of Slavic aspect / IV Конф. Комиссии по аспектологии Междунар. комитета славистов (Гётеборгский университет, 10 июня - 14 июня 2013 г.). Göteborg: Göteborgs universitet, 2013: 87-90 (Gothenburg Slavic Studies 3).

Kravar, Miroslav. „Aspektne osobitosti modalnih glagola (na srpsko-hrvatskom materijalu)“. Radovi Filozofskog fakulteta u Zadru 5/3, 1963/1964: 35-48.

Kravar, Miroslav. "Verbal Aspect and Relative Time: (The w h e n - Clause Test)". Radovi Filozofskog fakulteta u Zadru [II. dio] 17/10, 1977/1978: 149-163.

Lehmann, Volkmar. „On the relation between nonepisodic/nonlocalized, iterative, and omnitemporal situations“. [B:] M. Nilsson \& N. Zorikhina Nilsson (eds.). Семантический спектр слявянского вида / The semantic scope of Slavic aspect / IV Конф. Комиссии по аспектологии Междунар. комитета славистов (Гётеборгский университет, 10 июня - 14 июня 2013 г.). Göteborg: Göteborgs universitet, 2013: 96-98 (Gothenburg Slavic Studies 3).

\section{Извори}

Андрић, Иво. Жеђ. Београд: Просвета, 1963.

Бажов, Павел. «Малахитовая шкатулка». [В:] П. Бажов Малахитовая шкатулка. Москва: ФТМ, 1938.

Булгаков, Михаил Мастер и Маргарита. Москва: Художественная литератуpa, 1990.

Гоголь, Николай В. Мертвые души. Москва, 1946.

Игњатовић, Јаков, Вечити младожења. Београд: Српска књижевна задруга, 1910.

Капор, Момо. Ивана. Београд: Српска књижевна задруга, 2001.

Славистика XXII/2 (2018) 
Љубиша, Стјепан М. „Сједи криво, ал’ суди право“. [В:] Ст. М. Љубиша Причања

Вука Дојчевића. Београд: Српска књижевна задруга, 1902.

Нушић, Бранислав. Аутобиографија. Београд: Култура, 1947.

Нушич, Бранислав. Автобиография. Москва: Художественная литература, 1972.

Перевод В. Токарева.

Паустовский, Константин Г. Собрание сочинений в 8 т. Москва, 1969.

Пушкин, Александр С. Капитанская дочка. Москва, 1947.

Puškin, Aleksandr S. Kapetanova kći. Čačak, 2009. Preveo B. Kovačević.

Солженицын, Александр. И. В круге первом. Москва: ИНКОМ НВ, 1991.

Толстой, Лев Н. Хаджи-Мурат. Ленинград, Москва: Огиз, 1931.

Улицкая, Людмила. Лестница Якова. Москва, 2015.

Шмелев, Иван. Солнце мертвых. Берлин, 1923.

Чивилихин, Вадимир. Серебряные рельсы. Москва: Молодая гвардия, 1972.

Stanković, Borislav. Nečista krv, Beograd: Prosveta, 1946.

Ћопић, Бранко. Глава у кланцу, ноге на вранцу. Сарајево, 1971.

Ћосић, Добрица, Корени. Београд: Просвета, 1954.

Елена Недич

\section{ГЛАГОЛЬНЫЕ ФОРМЫ В ИТЕРАТИВНЫХ КОНСТРУКЦИЯХ В РУССКОМ И СЕРБСКОМ ЯЗЫКАХ}

\section{Резюме}

В данной работе делается попытка охватить и представить богатство и разнообразие глагольных средств и их итеративных значений, а также вариантов их эквивалентов в русском и сербском языках. Выделяются неограниченно-кратное, наглядно-примерное, квалификативное, пословичное значения, а также значения дезактуализованности, обыкновенного действия и эпизодического повторения. С помощью контрастивного анализа устанавливаются возможные варианты выражения данных значений. Анализируются формы совершенного и несовершенного вида, способы глагольного действия и некоторые специальные формы для выражения итеративных значений (конструкции с глаголом бывало, доводится, приходится, любить) в русском языке, а также видовые формы, форма потенциала и специальные конструкции для выражения итеративности (с модальными глаголами, с глаголами дешавати се, догађати се, волети и др.) в сербском языке.

Ключевые слова: итеративность, глагольная квантификация, хабитуальность. 